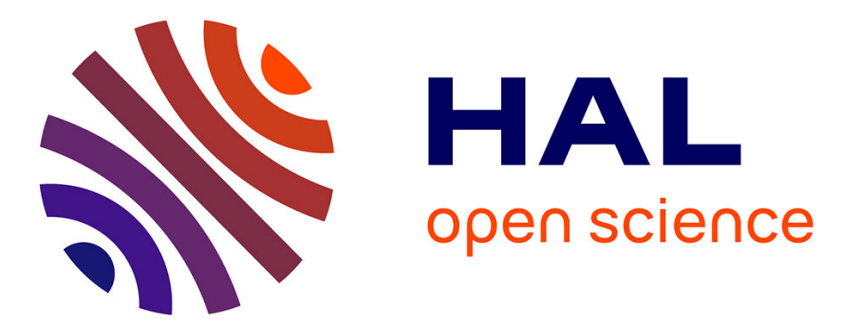

\title{
Use of rilpivirine in HIV-1 infected individuals in routine clinical practice from 2012 to 2017 in France
}

Valérie Potard, Sébastien Gallien, Ana Canestri, Dominique Costagliola

\section{To cite this version:}

Valérie Potard, Sébastien Gallien, Ana Canestri, Dominique Costagliola. Use of rilpivirine in HIV-1 infected individuals in routine clinical practice from 2012 to 2017 in France. Journal of Antimicrobial Chemotherapy, 2021, 76 (2), pp.467-476. 10.1093/jac/dkaa449 . hal-03179377

\section{HAL Id: hal-03179377 \\ https://hal.sorbonne-universite.fr/hal-03179377}

Submitted on 24 Mar 2021

HAL is a multi-disciplinary open access archive for the deposit and dissemination of scientific research documents, whether they are published or not. The documents may come from teaching and research institutions in France or abroad, or from public or private research centers.
L'archive ouverte pluridisciplinaire HAL, est destinée au dépôt et à la diffusion de documents scientifiques de niveau recherche, publiés ou non, émanant des établissements d'enseignement et de recherche français ou étrangers, des laboratoires publics ou privés. 
Use of rilpivirine in HIV-1 infected individuals in routine clinical practice from 2012 to 2017 in France

Valérie POTARD ${ }^{1 *}$, Sebastien GALLIEN ${ }^{2}$, Ana CANESTRI ${ }^{3}$, and Dominique COSTAGLIOLA ${ }^{1}$ on behalf of the French Hospital Database on HIV (FHDH ANRS $\mathrm{CO}^{\dagger}{ }^{\dagger}$ )

${ }^{1}$ Sorbonne Université, INSERM, Institut Pierre Louis d'Épidémiologie et de Santé Publique (IPLESP), Paris, France; ${ }^{2}$ AP-HP, Hôpital Henri Mondor, Service d'Immunologie et Maladies Infectieuses, Université Paris Est Créteil, Inserm U 955, Créteil, France; ${ }^{3}$ AP-HP, Hôpital de Tenon, Service des Maladies Infectieuses et Tropicales, Paris, France tMembers are listed in the Acknowledgements section

*Corresponding author: Valérie POTARD, INSERM U1136, 56 Bd V Auriol, CS 81393, 75646 Paris Cedex 13, France, valerie.potard@iplesp.upmc.fr, +33142164270

Short title: Use of rilpivirine in routine clinical practice
Abstract: 238 (250 words)
Text: 2833 (3500 words)
2 figures, 4 tables
2 supplementary tables 


\section{Abstract \\ Objectives:}

We assessed virological outcomes of rilpivirine use in France from 2012 to 2017, in three groups of people living with HIV (PLHIV):(1) antiretroviral (ARV)-naïve PLHIV;(2) ARVexperienced PLHIV switching to rilpivirine while failing therapy; and (3) ARV-experienced PLHIV switching to rilpivirine while virologically controlled.

\section{Methods:}

Virological success (VS) was defined as a plasma HIV-1 viral load (VL) $<50$ copies/mL and virological failure (VF) as two consecutive $\mathrm{VL}>50$ copies $/ \mathrm{mL}$ or one $\mathrm{VL}>50$ copies/mL followed by a treatment switch prior to the next VL measurement. The cumulative incidence of VS was assessed considering rilpivirine discontinuation, loss to follow-up, and death as competing risks, while estimates of cumulative incidence of VF accounted for loss to follow-up and death.

Results: Among the 2166 ARV-naïve PLHIV initiating rilpivirine, the four-year cumulative incidence of VS was $91.0 \%$ and was associated with baseline VL. Among the 2125 ARVexperienced PLHIV switching to rilpivirine while failing therapy, the four-year cumulative incidence of VS was $82.5 \%$ and was associated with lower VL, higher CD4, and less than three prior ARVs. Among the 11828 ARV-experienced PLHIV switching to rilpivirine while virologically controlled, the four-year cumulative incidence of VF was $9.6 \%$. The risk of VF was lower among MSM, for PLHIV with CD4 $\geq 500 / \mathrm{mm}^{3}$, without a prior AIDS event, or with a longer VL suppression at baseline.

Conclusion: Rilpivirine-containing regimens yielded high rates of viral suppression in most participants, while it was ineffective when used outside the marketing authorization in naïve participants. 


\section{Introduction}

Rilpivirine is a second-generation NNRTI that has been available in France since 2012. It is indicated for people living with HIV (PLHIV) with viral load (VL) $\leq 100000$ copies/mL and no NRTI and NNRTI resistance. Clinical trials have demonstrated the efficacy of rilpivirine associated with emtricitabine and tenofovir [TDF], in treatment-naïve PLHIV with VL $\leq 100000$ copies/mL. ${ }^{1,2,3}$ Others clinical trials have shown that the rilpivirine/emtricitabine/TDF combination can maintain virological suppression in antiretroviral (ARV)-experienced virologically-controlled PLHIV. ${ }^{4-8}$ In recent trials, the dual therapy dolutegravir/rilpivirine was non-inferior to a current triple antiretroviral therapy (ART) regimen in ARV-experienced virologically-controlled PLHIV at week 48 and efficacy and safety were maintained at week 100 .,10 $^{9,9}$

It is important to obtain data from real-life settings to assess how rilpivirine is used in routine care and evaluate its virological efficacy, as a complement to data from clinical trials. The purposes of this observational study were to describe the routine use of rilpivirine in France in ARV-naïve PLHIV, ARV-experienced PLHIV failing therapy, and ARV-experienced virologically-controlled PLHIV and to assess its effectiveness in terms of virological outcomes. We also aimed to assess whether the effectiveness was similar when rilpivirine was used in dual therapy versus in combination with three or more drugs. 


\section{Individuals and methods}

\section{Individuals and data sources}

The French Hospital Database on HIV (FHDH) is a hospital-based multicentre open cohort in which inclusions have been ongoing since $1989 .{ }^{11}$ Individuals are eligible if they have documented HIV-1 or HIV-2 infection and give their written informed consent to participate. Data are collected prospectively by trained research assistants using standardized forms which include demographic characteristics, biological markers such as the CD4 and plasma HIV RNA level, and antiretroviral treatments. The FHDH project was approved by the French data protection authority (Commission National de I'Informatique et des Libertés on 27 November 1991, Journal Officiel, 17 January 1992).

\section{Study population}

This study was restricted to HIV-1 infected individuals of at least 18 years of age who started rilpivirine between January 1, 2012 and December 31, 2017, at least one year before the last recorded FHDH visit in the centre, with available viral load (VL) and CD4 values within six months before initiating rilpivirine and at least one VL value after. If they satisfied the inclusion criteria, individuals were classified into one of the following groups: (1) ARV-naïve PLHIV; (2) ARV-experienced PLHIV switching to rilpivirine while failing therapy, and (3) ARV-experienced PLHIV switching to rilpivirine while virologically controlled ( $\mathrm{VL}<50$ copies $/ \mathrm{mL})$.

\section{Statistical analysis}

The principles of the analyses were the same as in a previous study assessing darunavir in a similar setting. ${ }^{12}$ The baseline for all analyses was the date of rilpivirine initiation. Continuous variables were expressed as medians and IQR and categorical variables as counts and percentages. Virological success (VS) was defined as a VL $<50$ copies/mL and virological failure (VF) as two consecutive $\mathrm{VL}$ values $>50$ copies $/ \mathrm{mL}$, or one $\mathrm{VL}$ value $>50$ copies $/ \mathrm{mL}$ followed by a treatment switch prior to the next $\mathrm{VL}$ measurement. For ARV-naïve PLHIV and ARV-experienced PLHIV switching to rilpivirine while failing 
therapy, we assessed the cumulative incidence of VS considering the discontinuation of rilpivirine as a competing risk (individuals who discontinue rilpivirine are likely to be those experiencing a slower reduction in $\mathrm{VL}$ ). This approach avoids a situation in which most individuals switch from rilpivirine and achieve a reduction in VL while on an alternative treatment. The events of loss to follow-up and death were also considered as competing risks for VS. For ARV-experienced PLHIV switching to rilpivirine while virologically controlled, the cumulative incidence of VF was estimated using an intention-to-continuetreatment approach, ignoring treatment change in order to also adopt a conservative approach. Only the events loss to follow-up and death were considered as competing risks. Individuals were considered to be "lost to follow-up" when there was an interval of more than 18 months between the last follow-up visit and the last database update for the centre in which they were followed. Individuals who experienced neither the outcome of interest nor the competing events were censored at the last follow-up or 48 months, whichever occurred first.

Univariable and multivariable competing-risk regression models, yielding subdistribution hazard ratios (sHR) were used to assess the influence of the type of combination (dual therapy, combination with three or more drugs) on VS or VF. ${ }^{13}$ The following potential confounding factors were accounted for the three groups: age, gender and HIV transmission group (MSM, injecting drug users, other men, other women), sub-Saharan origin, prior AIDS event, baseline CD4 $\left(<200 / \mathrm{mm}^{3}, 200-350 / \mathrm{mm}^{3}, 350-500 / \mathrm{mm}^{3}\right.$, $\geq$ $500 / \mathrm{mm}^{3}$ ), hepatitis C (HCV) antibody status (negative, positive), and hepatitis B surface antigen (HbsAg) status (negative, positive). Baseline VL ( $\leq 30000,30000-100000,>100$ 000 copies/mL) was also accounted for ARV-naïve PLHIV and ARV-experienced PLHIV switching to rilpivirine while failing therapy, as was the number of prior $\operatorname{ARVs}(\leq 3,4-6,>6)$ for ARV-experienced PLHIV switching to rilpivirine while failing therapy and the duration of viral suppression prior to baseline for ARV-experienced PLHIV switching to rilpivirine while virologically controlled. SAS software (v9.4; SAS Institute Inc, Cary, NC, USA) was 
used for all statistical analyses.

\section{Results}

\section{Baseline characteristics}

The baseline characteristics according to group are shown in Table 1. A total of 2166 ARV-naïve PLHIV initiated rilpivirine (group 1), 2125 ARV-experienced PLHIV switched to rilpivirine while failing therapy (group 2) and 11828 ARV-experienced PLHIV switched to rilpivirine while virologically controlled (group 3). No PLHIV started rilpivirine monotherapy. Only 7 ARV-naïve PLHIV started a dual therapy (0.3\%). Among ARVexperienced PLHIV who switched to rilpivirine while failing therapy, 76 received dual therapy (3.6\%) and among those who switched to rilpivirine while virologically controlled, 555 received dual therapy $(4.7 \%)$ of which most was with dolutegravir $(90.5 \%)$. Triple therapy with two NRTIs, particularly TDF and emtricitabine, was the most prescribed for all groups. A minority of ARV-naïve PLHIV initiated rilpivirine with VL>100 000 copies/mL (4.5\%) as well as ARV-experienced PLHIV switching to rilpivirine while failing therapy (6.0\%). A minority of ARV-naïve PLHIV had prior AIDS event (2.2\%), HCV coinfection (3.6\%) and HBV coinfection (2.8\%), while among ARV-experienced PLHIV overall, 19.3\% had a prior AIDS event, $11.3 \%$ were HCV coinfected and $6.0 \%$ HBV coinfected. The median duration of follow-up was 3.1 years (IQR: 2.0-4.0) for group 1, 3.3 years (IQR: 2.0-4.0) for group 2, and 3.3 years (IQR: 2.1-4.0) for group 3.

\section{ARV-naïve PLHIV}

Of the 2166 ARV-naïve PLHIV who initiated rilpivirine, 1950 achieved a $V L<50$ copies/mL, whereas 137 discontinued rilpivirine, 34 were lost to follow-up and three died before the control of VL. Cumulative incidence estimates showed the one-year probability of VS, discontinuation, loss to follow-up, and death to be $86.3 \%(95 \% \mathrm{Cl}, 84.8-87.8), 5.2 \%(95 \%$ $\mathrm{Cl}, 4.3-6.3), 1.1 \%(95 \% \mathrm{Cl}, 0.7-1.6)$ and $0.1 \%(95 \% \mathrm{Cl}, 0.0-0.3)$ respectively, and at four 
years to be $91.0 \%(95 \% \mathrm{Cl}, 89.6-92.4), 6.6 \%(95 \% \mathrm{Cl}, 5.7-7.6), 1.6 \%(95 \% \mathrm{Cl}, 1.2-2.3)$ and $0.1 \%(95 \% \mathrm{Cl}, 0.1-0.4)$ respectively. Individuals with baseline VL between 30000 and 100000 copies/mL or a baseline VL > 100000 copies/mL were less likely to achieve a $\mathrm{VL}<50$ copies $/ \mathrm{mL}(\mathrm{sHR}=0.71,95 \% \mathrm{Cl}, 0.65-0.78$ and $\mathrm{sHR}=0.48,95 \% \mathrm{Cl}, 0.39-0.58$, respectively) (Figure 1a and Table 2). The type of combination (dual therapy or combination with three or more drugs) was not significantly associated with VS. Neither HBV nor HCV coinfection were associated with VS.

The main reason for discontinuing rilpivirine before VS were adverse events $(43.9 \%)$ and treatment failure (23.4\%) (Supplementary table1). Among the 1950 individuals with VS, 294 discontinued rilpivirine after reaching a $\mathrm{VL}<50$ copies $/ \mathrm{mL}$, and the probability of discontinuing rilpivirine at four years was $20.4 \%(95 \% \mathrm{Cl}, 18.5-22.6)$. The main reason for discontinuing rilpivirine after VS was adverse events (49.1\%).

\section{ARV-experienced PLHIV switching to rilpivirine while failing therapy}

Among the 2125 ARV-experienced PLHIV switching to rilpivirine while failing therapy, 1736 reached a $\mathrm{VL}<50$ copies/mL, whereas 302 discontinued rilpivirine, 29 were lost to follow-up and 7 died before reaching this endpoint. Cumulative incidence estimates showed the one-year probability of VS, discontinuation, loss to follow-up, and death to be 76.1\% (95\% Cl, 74.4-77.8), 10.5\% (95\% Cl, 9.2-11.9), $2.2 \%(95 \% \mathrm{Cl}, 2.0-2.5)$, and $0.1 \%$ $(95 \% \mathrm{Cl}, 0.0-0.1)$ respectively, and at four years to be $82.5 \%(95 \% \mathrm{Cl}, 80.8-84.1), 14.8 \%$ (95\% Cl, 13.2-16.6), 7.6\% (95\% Cl, 7.1-8.2), and $0.6 \%(95 \% \mathrm{Cl}, 0.4-0.8)$ respectively. Individuals with a baseline VL between 30000 and 100000 copies/mL or baseline VL > 100000 copies $/ \mathrm{mL}$ were less likely to achieve a $\mathrm{VL}<50$ copies $/ \mathrm{mL}(\mathrm{sHR}=0.65,95 \% \mathrm{Cl}$, 0.57-0.74 and $\mathrm{sHR}=0.55,95 \% \mathrm{Cl}, 0.46-0.67$, respectively) (Figure $1 \mathrm{~b}$ and Table 3 ). Individuals who were experienced to more than three prior ARVs or who had baseline CD4 $<200 / \mathrm{mm}^{3}$ were also less likely to reach a $\mathrm{VL}<50$ copies $/ \mathrm{mL}$, whereas neither the 
type of combination nor the coinfection with HBV or HCV were significantly associated with VS (Table 3).

The main reason for the discontinuation of rilpivirine before VS was treatment failure (38.1\%) (Supplementary table1). Among the 1736 individuals with VS, 430 discontinued rilpivirine after reaching a $\mathrm{VL}<50$ copies $/ \mathrm{mL}$ and the probability of discontinuing rilpivirine at four years was $31.4 \%(95 \% \mathrm{Cl}, 29.2-33.8)$. The main reason for discontinuing rilpivirine after VS was adverse events (30.4\%).

\section{ARV-experienced PLHIV switching to rilpivirine while virologically controlled}

Among the 11828 ARV-experienced PLHIV switching to rilpivirine while virologically controlled, 967 experienced VF (872 with two consecutive VL > 50 copies/mL and 95 with one $\mathrm{VL}>50$ copies/mL followed by a treatment switch prior to the next $\mathrm{VL}$ measurement), whereas 728 were lost to follow-up and 45 died. Cumulative incidence function estimates showed the one-year probability of VF, loss to follow-up, and death to be $4.5 \%(95 \% \mathrm{Cl}$, 4.1-4.9), $2.2 \%(95 \% \mathrm{Cl}, 2.0-2.5)$, and $0.1 \%(95 \% \mathrm{Cl}, 0.0-0.1)$ respectively, and at four years to be $9.6 \%(95 \% \mathrm{Cl}, 9.1-10.2), 7.6 \%(95 \% \mathrm{Cl}, 7.1-8.2)$, and $0.6 \%(95 \% \mathrm{Cl}, 0.4-0.8)$ respectively.

As shown in Table 4, MSM had a lower risk of VF than the other transmission groups. A shorter duration of viral suppression, prior AIDS event, or baseline CD4 $<500 / \mathrm{mm}^{3}$ were associated with a higher risk of VF. The probability of VF at four years after switching to rilpivirine was ranging from $6.1 \%(95 \% \mathrm{Cl}, 5.3-7.0)$ in participants for whom the duration of viral suppression was $>5$ years, to $13.7 \%(95 \% \mathrm{Cl}, 12.6-14.9)$ among individuals with a duration of viral suppression $<2$ years (Figure $2 a$ ).

PLHIV switching to dual therapy had a median duration of follow-up of 1.7 years (IQR: 1.1-2.4) and those switching to combination with three or more drugs 3.4 years (IQR: 2.24.0). The one-year and four-year probabilities of $\mathrm{VF}$, were $2.8 \%(95 \% \mathrm{Cl}, 1.9-4.1)$ and $6.1 \%(95 \% \mathrm{Cl}, 4.1-9.2)$ among those receiving dual therapy, and $4.6 \%(95 \% \mathrm{Cl}, 4.2-5.0)$ 
and $9.8 \%(95 \% \mathrm{Cl}, 9.2-10.5)$ among those receiving combination with three or more drugs, respectively (figure 2b). There were significant differences in characteristics of ARV-experienced PLHIV switching to dual therapy and those switching to three or more drugs while virologically controlled (supplementary table 2). After accounting for those differences in the multivariable model, there was no evidence of a difference in the risk of VF between dual therapy and combination with three or more drugs (sHR=0.75 $(95 \% \mathrm{Cl}$, 0.49-1.15)).

A total of 2928 individuals discontinued rilpivirine, of whom 2278 individuals $(77.8 \%)$ had not experienced VF. Among individuals who had not experienced VF, the probability of discontinuing rilpivirine at four years was $26.3 \%(95 \%, 25.4-27.3)$. The main reason for discontinuation was adverse events (60.2\%) (Supplementary table1).

\section{Discussion}

In this observational study, we showed that rilpivirine-based regimens were associated with a virological success rate $>82 \%$ at four years, for the three groups: ARV-naïve (group 1), or ARV-experienced PLHIV switching to rilpivirine while failing therapy (group 2) or while virologically controlled (group 3). Rilpivirine was predominantly prescribed in ARV-experienced PLHIV switching to rilpivirine while they were virologically controlled (73\%) and according to the indication of the marketing authorization, mainly to PLHIV with a VL $\leq 100000$ copies / mL.

The one-year VS rate of $86 \%$ in ARV-naïve individuals on rilpivirine was similar to that reported in randomized controlled trials, such as the Echo trial (83\% at week 48), Thrive trial $(86 \%$ at week 48$)$ or Star trials $(86 \%$ at week 48$) .{ }^{1,2,3}$ The rates of discontinuation at one-year or four years were low $(5.2 \%$ or $6.6 \%)$. In an observational study from the ICONA cohort, the rate of discontinuation was higher $(10.1 \% ; 95 \% \mathrm{Cl}[7.6-12.7 \%]$ at 2years). ${ }^{14}$ The main reasons for discontinuation in this ICONA study were similar to those in our study (treatment failure, $25.0 \%$ versus $23.4 \%$ and adverse events, $47.1 \%$ versus 
43.9\%). While HBV or HCV coinfection were associated with a lower VS rate at week 48 in the pooled data of the Echo and Thrive trials, we did not find such a trend in our study, even if the proportions of HBV or HCV coinfected PLHIV were similar. ${ }^{15}$

To our knowledge no study has evaluated rilpivirine in ARV-experienced PLHIV switching while failing therapy. Given that marketing authorization is restricted to ARV-naïve-orexperienced PLHIV with VL $\leq 100000$ copies / mL, rilpivirine should not be used outside this context. In our study, $6 \%$ of ARV-experienced PLHIV switching while failing had a baseline VL>100 000 copies $/ \mathrm{mL}$. Thus, it was not surprising that the rates of VS was only $54 \%$ at one year. Even among those who had a baseline VL between 30000 and 100000 copies $/ \mathrm{mL}$, the rate of VS with the rilpivirine regimen was only $62 \%$ at one year. The oneyear VS rate of $80 \%$ in PLHIV on rilpivirine with a baseline VL $\leq 30000$ copies $/ \mathrm{mL}$ was close to that estimated in ARV-naïve PLHIV.

Only $4.7 \%$ of ARV-experienced PLHIV with controlled VL switched to rilpivirine dual therapy, probably because the rilpivirine/dolutegravir single-tablet regimen was not yet available during the study period. This combination was only marketed in France in 2018. In our observational study, the rate of VF at one year among ARV-experienced PLHIV switching to rilpivirine while virologically controlled was $4.5 \%$, higher than that in the Spirit (2.5\%), GS-US-366-1160 (1.0\%) or Sword trials $(0.6 \%)$, with a possible explanation being a shorter duration of VL suppression in our study. A prior AIDS event, baseline CD4 $<500 / \mathrm{mm}^{3}$, or shorter duration of viral suppression were independently associated with a higher risk of VF, as in many switch studies. ${ }^{12,16}$ Dual therapy consisting of rilpivirine with INI or boosted PI was associated with a response rate not significantly different from that of triple therapy and, even accounting for the observational nature of our study, it is reassuring.

The main strength of our study was its large size, 48-month follow-up, and routine clinical setting, providing additional evaluation of the use of rilpivirine in combination with one or 
more ARVs in all groups of patients. In this observational setting, we were unable to adjust the results for the genotypic susceptibility score or adherence which are not recorded in the FHDH. However, we feel that our results are nevertheless robust, as we adjusted for the number of prior ARVs in ARV-experienced PLHIV switching to rilpivirine while failing therapy and for prolonged viral suppression in ARV-experienced PLHIV switching to rilpivirine while virologically controlled.

In conclusion, this real-world nationwide cohort shows that rilpivirine was used in France from 2012 to 2017 in ARV-naïve and ARV-experienced PLHIV switching to rilpivirine while failing therapy mainly with a VLs100 000 copies $/ \mathrm{mL}$ as per the marketing authorization and in ARV-experienced PLHIV switching to rilpivirine while virologically controlled with a high level of efficacy, similar to that in clinical trials. When rilpivirine was used outside the marketing authorization, it was not effective. Our results show no significant difference in efficacy between the use of dual and triple therapy in ARV-experienced PLHIV switching to rilpivirine while virologically controlled. 


\section{Acknowledgments}

\section{Clinical Epidemiology Group of the FHDH-ANRS CO4}

- Scientific committee: S Abel, S Abgrall, C Allavena, H Bazus, A Becker, F Benezit, P Bouvet de la Maisonneuve, S Bregigeon, A Brugnon, F Caby, R Calin, A Cheret, D Costagliola, P de Truchis, B Denis, C Duvivier, P Enel, H Fischer, J Ghosn, M Goussef, S Grabar, F Huber, C Jacomet, V Joly, C Katlama, M A Khuong, A Makinson, L Marchand, G Martin-Blondel, S Matheron, J L Meynard, P Miailhes, M Nacher, E Piet, L Piroth , M Ploquin, V Rabier , O Robineau, E Rouveix Nordon, P Tattevin.

- COREVIH coordinating center: French Ministry of Health ( $T$ Kurth), Technical Hospitalization Information Agency, ATIH (N Jacquemet).

- Statistical analysis center: UMRS 1136 INSERM et UPMC (D Costagliola, Principal investigator, S Abgrall, S Grabar, S Leclercq, L Lièvre, E Marshall, V Potard, H SelingerLeneman).

- COREVIH:

Paris area:

Corevih Ile de France Centre (Paris-GH Pitié-Salpétrière : E Caumes, C Katlama, O Benveniste, M A Valantin, R Tubiana, R Palich, A Simon, R Agher, C Blanc, L Lenclume, Y Dudoit, N Qatib, M Pauchard, D Beniken; Paris-Hôpital Saint-Antoine : K Lacombe, L Fonquernie, N Valin, M Brucker, M Sebire-Le Cam, J L Lagneau, J Lamarque, C Tran ; Paris-Hôpital Tenon : G Pialoux, R Calin, J Chas, M Hamidi, A Adda-Lievin, P Thibaut, M Mebarki).

Corevih lle de France Est (Hôpital Saint Louis : J M Molina, C Lascoux, C Pintado, N de Castro, B Denis, W Rozenbaum, D Ponscarme, J Zeggagh, F ClaveL, A Aslan, M Lafaurie, J Gras, V Manda, G Liegeon, M Tateo, D Feyeux, G Hamet, C Colladant ; Hôpital Lariboisière : $P$ Sellier, A Rami, M Diemer, L Azemar, M Parrinello, G CastorAlexandre ; CH d'Arpajon : S Lamy ;GHEF de Coulommiers : B Devaux, S Tassi ; GHEF de Marne la Vallée : M Machado, P Simon, E Froguel, A Barrelet, O Senard; CH de Fontainebleau D Cote, C Routier, H Roukas ; $\mathrm{CH}$ de Melun S Diamantis, N Vignier ; GHNE de Longjumeau : O Banini ; CHSF de Corbeil Essonnes : A Chabrol, A Henn, T Gabas, O Son, N Aghe ; CH de Bligny : C Dupont, P Chardon ; Hôpital Avicenne-Bobigny : O Bouchaud, A Benmammar, L Traore ; CHI Le RaincyMontfermeil : F Bidegain, L Mansouri ; CHI André Grégoire-Montreuil : M H Andre, G Fremont ; Hôpital Jean Verdier : J Bottero, C Palacios, F Mfutila, A Benmammar). Corevih lle de France Nord (Hôpital Bichat-Claude Bernard : Y Yazdanpanah, R Landmann C Mackoumbou-Nkoula, M Chansombat, C Godard, Z Julia, F Louni, A Ndiaye, L Loste, S Le Gac ; CH Delafontaine-Saint-Denis : M A Khuong-Josses, M Poupard, N Sayre, B Frison, C Charpentier, S Cossec ; CH René DUBOS-Pontoise : S Harent, L Blum, S Stegmann, G Grain ; Hôpital Beaujon-Clichy : B Fantin, A Villemant, A Lefort, V Zarrouk, V De Lastours, E Canoui, A Galy, V Honsel, A Becharef ; CH de Gonesse : D Seret Begue, D Troisvallets, A Becharef).

Corevih Ile de France Ouest (CH de Mantes-la-Jolie : F Granier, J J Laurichesse, B Montoya; IHFB de Levallois -Perret : D Giely, G Force; CHI de Poissy : C VeyssierBelot, H Masson, Y Welker, C Leclerc ; CH de Versailles : A Greder-Belan, C GodinCollet, D Bornarel ; CHI de Meulan-les-Mureaux : B Coudert, C Kakon, T Akpan, M Marcou ;Hôpital Louis-Mourier : H Duboc, E Mortier, A F Zeng; Hôpital Ambroise Paré : T Hanslik, J E Kahn, E Rouveix Nordon, S Greffe, S Trad, L Coutte, M, de Laroche, A Bauvois, A Freire Maresca, S Chenakeb ; Hôpital Raymond-Poincaré : C Perronne, P de Truchis, H Lepinay ; Hôpital Max Fourestier : L El Mansouf, V Daneluzzi, V Manceron, E Mortier, G Bouteria ; Hôpital Foch : F Ackermann, E Fourn, C Majerholc, A Fadli ; CH d'Argenteuil : P Genet, F Caby, Bwifaq, J Gerbe). 
Corevih lle de France Sud (Hôpital Cochin : O Launay ; Hôpital Européen Georges Pompidou : L Weiss, J Pavie, D Batisse, M Karmochkine, M Meghadecha, ML Lucas, M Ptak, C Jung ; Hôpital Hôtel Dieu : J P Viard, D Salmon, L Slama, V A LetembetIppet, R Usubillaga, M Kalambay, R Ben Rayana, A Cros, M J Dulucuq, V Le-Baut, M P Pietri ; Hôpital Necker-Enfants malades et Centre Médical de l'Institut Pasteur : C Aguilar, F Alby-Laurent, K Amazzough, G Benabdelmoumen, P Bossi, G Cessot, C Charlier, P H Consigny, C Duvivier, K Jidar, E Lafont, F Lanternier, M Lecuit, E Pichard, J Leporrier, O Lortholary, C Louisin, J Lourenco, P Parize, B Pilmis, C Rouzaud, F Touam ; Institut Mutualiste Montsouris : M Gayraud, L Bodard ; Hôpital AntoineBéclère : S Abgrall, I Kansau, V Chambrin, S Poirier ; CHU Kremlin-Bicêtre : C Goujard, S Jaureguiberry, Vittecoq A Castro Gordon, A Cheret, Y Quertainmont, E Teicher, O Derradji, M Bary, C Couzigou, J Y Liotier, M Merad, P Benoist, M Mole, F Churaqui, A S Keita ; Hôpital Henri Mondor : J D Lelievre, Y Levy, S Gallien, G Melica, W Vindrios, J L Lopez-Zaragoza, C Chesnel, R Ben Rayana ; CHI DE Créteil : I Delacroix, V Garrait, B Elharrar, E Krastinova, L Richier ; CHI de Villeneuve-StGeorges : O Patey S Dellion).

Outside Paris area :

Corevih de l'Arc Alpin (CHU Grenoble Alpes : P Leclercq, P Pavese, S Aggoun, S Dufresnes; CH Alpes Leman : D Leduc, S Megessier ; CH d'Annecy Genevois : V Vitrat, E Piet, A Valran; $\mathrm{CH}$ de Chambery : E Forestier, O Rogeaux, A Curiallet ; $\mathrm{CH}$ de Thonon les Bains : $F$ Bissuel ; Hôpital de Sallanches : $F$ Lange ; $\mathrm{CH}$ Bourgoin Jallieu : M Fabre; CH Vienne : A Bouaziz, L Adelaide ; CH de Voiron : C HenryOstian, M Guillaume).

Corevih Auvergne-Loire (CHU de Clermont-Ferrand: H Laurichesse, C Jacomet, E Goncalves ; CHU de St Etienne : P Berthelot, A Fresard, V Ronat ; CHG Henri Mondor : S Trouiller, I Masse-Chabredier, C Theis ; CH Emile Roux : O de Tauriac ; $\mathrm{CH}$ de Roanne : L Moiron, $\mathrm{C}$ Blanc ; $\mathrm{CH}$ de Montluçon : O Antoniotti, E Nehme ; $\mathrm{CH}$ de Moulins-Yzeure : A D Anthony Moumouni, Y Rousseau ; CH Jacques Lacarin : A M Milesi-Lecat, F Gourdon ).

Corevih Bourgogne Franche-Comté (CHU de Dijon : L Piroth, P Chavanet, M Duong, M Buisson, A Waldner-Combernoux, S Mahy, A Salmon-Rousseau, M Blot, C Esteve, C François-Xavier, C Charles, S Gohier ; Hôpital Pierre Bérégovoy-Nevers : H Djerad, S Goteni; CH de Sens : A Creuwels ; CHRU de Besançon : C Chiroue, F Aubin C Drobacheff Thiébaut, A Foltzer, O Babre, E Chevalier ; $\mathrm{CH}$ de Chalon-sur-Saône : B Martha ; CH de Mâcon : J P Kristermann ; Hôpital Nord Franche-Comté-Belfort : V Gendrin, G Loriol GH de la Haute-Saône-Vesoul : C Merle).

Corevih Bretagne (CHRU de Rennes : P Tattevin, C Arvieux, M Revest, F Souala, S Patrat-Delon, M Baldeyrou, J M Chapplain, F Bénézit, M Dupont, A Maillard, F Lemaître, E Polard, J Vivent, J P Sinteff, T Jovelin, C Morlat, M Poisson, J P Sinteff ; CH de SaintMalo : E Goarant, M Dupont ; CH de Saint-Brieuc : M Valence, R Buzele; CHIC de Quimper : P Perfezou, P Hutin, J P Talarmin, L Khatchatourian, J C Duthe ; CH des Pays de Morlaix : A Lamour, J B Euzen ; CHRU La Cavale Blanche-Brest : $L$ de SaintMartin, V Bellein, J C Duthé, S Briand-Feve ; CHBA de Vannes : Y Poinsignon, G Corvaisier, M Gousseff, M Abdel Fattah, V Mouton Rioux, K Touboulic ; CHBS de Lorient : P Moreau, M Niault-Dollon, M F le Coz, O Luycx, A Lorléac'h, N Rouzic : CH du Centre Bretagne : J M Le Roux)

Corevih Centre-Val de Loire (CHRU Tours : L Bernard, O Bourgault, I Arnault, V Latkowski ; CH Bourges: A Maakaroun, Y Guimard, M Tissinie ; CH Vierzon: J Agbodjan ; CH Chartres: O Raffy, I Darasteanu, G Thomas, C Boulard ; CH Dreux : V Papillon, O Brasse, C Poirier; $\mathrm{CH}$ de Châteauroux: C Allais ; $\mathrm{CH}$ de Blois et de Vendôme: A Chekroun, V Cueille-Descarpentries; CHR d'Orléans : T Prazuck, L Hocqueloux, De Dieuleveult) 
Corevih Grand-Est (CHU de Strasbourg : D Rey, M Partisani, V Martin, P Fischer ; CHR Mulhouse Sud Alsace : G Beck-Wirth, M Benomar ; Hôpitaux civils-Colmar : M Martinot, M Mohseni Zadeh, S Gravier, T Bonijoly, A Pachart ; CHRU de Nancy : B Hoen, M Delestan, M P Bouillon ; CHI Emile Durkheim-Epinal : M H Schuhamcher, I Beguinot ; Polyclinique Saint-André-Courlancy : C Strady ; Hôpital Robert Debré - CHRU de Reims : F Bani-Sadr, I Kmiec ; CHR Metz-Thionville : C Robert, P Muller, Z Cavelli, R Sibiescu, J Pouaha, M A Bucher; CH de Troyes: P Chauveau-Jouve, S Pavel, L Fevre) Corevih Hauts-de-France (CH Tourcoing : E Senneville, O Robineau, M Digumber, $P$ Cornavin, M Lombard, N Decaux ; CH de Compiègne : A L Lecapitaine, M Tonnelier, A Bouras ; CH de Creil : N Landgraf, F Cordier ; $\mathbf{C H}$ de Beauvais : K Ghomari, R Barruet ; CH de Lens : H Bazus, E Aissi, A Legrain N Van Grunderbeeck, M Karas ; CH de Boulogne-sur-Mer : P Bataille ; CHU d'Amiens : J L Schmit, J P Lanoix, N Mathon, M Lombard ; CH de Soissons : A Hachemi ; $\mathbf{C H}$ de Laon : K Ainine ; $\mathbf{C H}$ de Saint-Quentin : Y Douadi)

Corevih Lyon-Vallée du Rhône (Hospices civils de Lyon : C Chidiac, M Plantier, N Danelon, S Degroodt, N Benmakhlouf, F Moncorge ; Hôpital d'Instruction des armées Desgenettes -Lyon: L Karkowski ; CH de Bourg-en-Bresse : N Canu, D Bouhour, P Granier, C Decouchou, E Racamier ; Hôpital Nord-Ouest-Villefranchesur-Saône : G David, R Bricca ; CVMV-Villeurbanne : B Issartel ; CH d'Ardèche Méridionale-Aubenas : M A Arthus ; $\mathrm{CH}$ d'Ardèche-Nord-Annonay : J M Marc, $E$ Legrand ; Virages Santé-Lyon : C Coudeyras, J M Livrozet ; $\mathbf{C H}$ de Valence: H Champagne, A Dureault, L Letranchant, C Reynaud, J Saison)

Corevih Normandie (CHU de Caen : P Goubin, S Dargere, R Verdon ; CH de Saint Lô : J Fouchard, C Briere, A Nicolle ; CHI Elbeuf-Louviers-Val de Reuil : L Chauffrey, D Theron ; Hôpital Charles-Nicolle-Rouen : F Caron, M Etienne, D Theron, S Plumecocq, G Unal ; CH de Dieppe : S Robaday Voisin ; Hôpital Jacques Monod-Le Havre : N Elforzi, A Vandendriessche, C Guillois)

Corevih Nouvelle-Aquitaine (CH d'Angoulème : A Riché, S Males, M Grosset, E C Ngo Bell, G Arnou ; CH de Chatellerault : G Romero De Avila, A Elsendoorn ; $\mathbf{C H}$ de Jonzac-Saintonge-Saintes- Saint-Jean d'Angely : T Pasdeloup ; CH de Niort : S Sunder, A Dos Santos, V Goudet, K Schepers, P Gougeon ; CH de Royan : P Mottaz; CHI du Pays de Cognac : S Hebert ; CHU de Poitiers : F Cazenave-Roblot, G Le Moal ; CHU Dupuytren - Limoges : J F Faucher, C Genet, J Pascual ; G H de La Rochelle : F Roblot, G Le Moal, G Beraud, M Catroux, D Plainchamp; CH de Brive : B Abraham) Corevih Occitanie (CH d'Albi : J M Merault, M Chauveau, M A Laffont ; CH d'Alès : D Bastide, T Fraisse, A Soualah ; CH de Bézier : E Oziol, M L Casanova ; $\mathrm{CH}$ de Bigorre - Tarbes : C Dingremont, Y Leveneur, A Soto, B Marchou ; CH de Cahors : S Sire, V Remy ; CH Jacques Puel - Rodez : F Abdo, M Loriette, S Ray, B Albinet, H Frahier, B Guerin ; CH St Clair - Sète : ; CH St-Jean - Perpignan : H Aumaitre, M Saada, F Roustant, L Pinheiro ; GHU Caremeau - Nîmes : A Sotto, I Rouanet, R Doncesco ; Hôpital Gui de Chauliac - Montpellier : J Reynes, A Makinson, F Sebastiani, C Fernandez, C Tramoni, C Blot ; Hôpital J. Ducuing - Toulouse : F Gaches, D Garipuy, M Michaud, A Bicart-See, E Bonnet, F Trognko ; Hôpital Purpan - CHU de Toulouse : P Delobel, P Lansalot-Matras, M Marcel, C Rastoll, S Lagarrigue, A Frelat) Corevih PACA Est (CH d'Antibes : A Lanteri, E Denis, S Tempesta, A Vallejo ; CH de Nice : P Pugliese, V Mondain, E Cua, N Oran, I Touitou ; CH de Cannes : M Vassalo, N Oran, E Escach Wessels ; $\mathbf{C H}$ Général de Grasse Clavary : $P$ Y Dides ; $\mathbf{C H I}$ de Fréjus : P Del Giudice, T Hubiche, V Courbon ; CH de Draguignan : A Boumallassa, A Mothes, C Girod-Jouffroy, S Gobin).

Corevih PACA Ouest-Corse (Marseille-Hôpital de la Conception: P Enel, R Sambuc, MS Antolini-Bouvenot, P Druart, L Meddeb, I Ravaux, A Menard, C Tomei, C Dhiver, H Tissot-Dupont; Marseille-Hôpital Nord: J Moreau, S Mokhtari, MJ Soavi, V Thomas; Marseille-Hôpital Sainte-Marguerite: I Poizot-Martin, S Bregigeon, O Faucher, V Obry- 
Roguet, AS Ritleng, N Petit; Marseille-Centre pénitentiaire des Baumettes: C Bartoli, JM Ruiz, D Blanc; CH d'Aix-En-Provence: T Allegre, M Sordage, JM Riou, C Faudon; $\mathrm{CH}$ d'Avignon: B Slama, H Zerazhi, O Boulat, S Chebrek, M Beyrne; $\mathrm{CH}$ de Digne Les Bains: P Granet Brunello; $\mathbf{C H}$ de Gap: L Pellissier, D Bonnabel; $\mathbf{C H}$ de Martigues: $\mathrm{R}$ Cohen Valensi, B Mouchet, G Mboungou; CHI de Toulon: A Lafeuillade, E Hope-Rapp, G Hittinger, G Philip, V Lambry).

Corevih Pays de la Loire (CHU de Nantes : F Raffi, C Allavena, E Billaud, D Boutoille, C Deschanvres, B Gaborit, P Le Turnier, V Reliquet, S Sécher, M Cavellec, E Paredes, A Soria ; CH de Saint-Nazaire : S Hily, C Michau, N Pouhaut ; CHU d'Angers : P Abgueguen, V Dubée, V Delbos, V Rabier, Y M Vandamme, H Cormier, D Sanderink, R Mahieu, M de La Chapelle, P Fialaire, S Rehaiem ; CH de Cholet : S Monnereau, J P Breux, L Seguin ; CH de Laval : R Vatan, F Dangeul-Potier ; $C H$ du Mans : H Hitoto, $S$ Blanchi, N Crochette, J B Laine, L Perez, F Dangeul ; CH de La Roche-sur-Yon : P Perre, S Leautez, D Merrien, T Guimard, O Bollengier Stragier, M Morrier, D Boucher, P Point, J L Esnault, H Durand, A Pegeot, L Laine, T Jovelin, H Pelerin).

Overseas:

Corevih Guadeloupe (CHU de Pointe-à-Pitre : P M Roger, I Fabre, I Lamaury, B Tressieres, E Duvallon, K Samar; CH de Basse-Terre : N Baillet, F Boulard, M C Receveur, C Desfontaines ; CH Saint-Martin: : S Paucod, C Clavel, C Daniel, V Walter),

Corevih Guyane (CHG de Cayenne: M Nacher, S Soyon, K Verin, L Saint-Louis, K Bienvenu, B Guarmit, A Tricoche).

Corevih Martinique (CHU de Fort-de-France: A Cabie, S Abel, L Cuzin, S PierreFrançois, K Guitteaud, J M Turmel, K Rome, D de Majoubert, J Bavay).

Corevih Océan Indien (St Denis-CHU Félix Guyon : M P Moiton, C Ricaud, B Kuli, C Gaud, M Lagrange-Xelot, S Hoang, G Wartel, R Rodet, C Sautron, I Rigollier ; St Pierre-GH Sud Réunion : P Poubeau, R Manaquin Y Koumar, C Duronea; $\mathrm{CH}$ de Mayotte : S Permal, M Jean). 


\section{Funding}

FHDH is supported by the Agence Nationale de Recherches sur le Sida (ANRS), Institut National de la Santé et de la Recherche Médicale (INSERM) and the French Ministry of Health. This study was funded by Janssen.

\section{Transparency declaration}

DC reports HIV grants from Janssen (2017-2018, 2019-2020) and MSD France (20152017), personal fees from Janssen (2016, 2018), MSD France 2017) and Gilead (2018, 2020) for lectures, personal fees from Merck Switzerland (2017) for consultancy, outside the submitted work. AC has received lecturer or travel fees from Gilead, Janssen, MSD and ViiV during the last three years. SG has received lecturer or travel fees from Gilead, Janssen, MSD, ViiV and Pfizer during the last three years. VP has conducted postmarketing studies for Janssen during the last three years.

\section{Author's contribution}

DC and VP designed the study, analyzed the data, drafted the manuscript, had full access to the data and had final responsibility for the decision to submit the study for publication. AC and SG revised the analysis plan. All authors were involved in the interpretation of the data and critical revision of the manuscript and approved the final version. 


\section{References}

1. Molina JM, Cahn P, Grinsztejn B, et al. Rilpivirine versus efavirenz with tenofovir and emtricitabine in treatment-naive adults infected with HIV-1 (ECHO): a phase 3 randomised double-blind active-controlled trial. Lancet 2011; 378: 238-246

2. Cohen CJ, Andrade-Villanueva J, Clotet B, et al. Rilpivirine versus efavirenz with two background nucleoside or nucleotide reverse transcriptase inhibitors in treatment-naive adults infected with HIV-1 (THRIVE): a phase 3, randomised, non-inferiority trial. Lancet 2011; 378: 229-237

3. Cohen CJ, Wohl D, Arribas JR, et al. Week 48 results from a randomized clinical trial of rilpivirine/emtricitabine/tenofovir disoproxil fumarate vs. efavirenz/emtricitabine/tenofovir disoproxil fumarate in treatment-naïve HIV-1-infected adults. AIDS 2014; 28: 989-997

4. Palella FJ, Fisher M, Tebas $P$, et al. Simplification to rilpivirine/emtricitabine/tenofovir disoproxil fumarate from ritonavir-boosted protease inhibitor antiretroviral therapy in a randomized trial of HIV-1 RNA-suppressed participants. AIDS 2014; 28: 335-344

5. De Jesus E, Ramgopal M, Crofoot G, et al. Switching from efavirenz, emtricitabine, and tenofovir disoproxil fumarate to tenofovir alafenamide coformulated with rilpivirine and emtricitabine in virally suppressed adults with HIV-1 infection: a randomised, doubleblind, multicentre, phase 3b, non-inferiority study. Lancet HIV 2017; 4: e205-213

6. Petchkum P, Sungkanuparph S, Kiertiburanakul, et al. Efficacy of Rilpivirine-Based Regimens as Switch Therapy From Nevirapine-Based Regimens in Human Immunodeficiency Virus-Infected Patients With Virological Suppression: A Randomized Controlled Trial. Open Forum Infect Dis 2019; 6: 1-8 https://doi.org/10.1093/ofid/ofz155

7. Wiriyatanakorn $S$ and Sungkanuparph S. Switching Tenofovir/Emtricitabine/Efavirenz (TDF/FTC/EFV) to TDF/FTC/Rilpivirine vs Continuing TDF/FTC/EFV in Human Immunodeficiency Virus-Infected Patients With Virological Suppression: A Randomized Controlled Trial. Open Forum Infect Dis 2019; 6: 1-4 https://doi.org/10.1093/ofid/ofz297

8. Munderi P, Were E, Avihingsanon A, et al. Switching at Low HIV-1 RNA into Fixed Dose Combinations: TDF/FTC/RPV is non inferior to TDF/FTC/ EFV in first-line suppressed patients living with HIV. S Afr J HIV Med. 2019; 20: a949.

9. Llibre JM, Hung CC, Brinson C, et al. Efficacy, safety, and tolerability of dolutegravirrilpivirine for the maintenance of virological suppression in adults with HIV-1: phase 3, randomised, non-inferiority SWORD-1 and SWORD-2 studies. Lancet 2018; 391: 839849

10. Aboud M, Orkin C, Podzamczer D, et al. Efficacy and safety of dolutegravir-rilpivirine for maintenance of virological suppression in adults with HIV-1: 100-week data from the randomised, open-label, phase 3 SWORD-1 and SWORD-2 studies. Lancet 2019; 6: 576-587

11. Mary-Krause M, Grabar S, Lièvre L, et al. Cohort Profile: French hospital database on HIV (FHDH-ANRS CO4). Int J Epidemiol 2014; 43: 1425-1436 
12. Potard V, Canestri A, Gallien S, et al. Use of darunavir in HIV-1-infected individuals in routine clinical practice from 2012 to 2016 in France. JAC 2019; 74: 3305-3314

13. Andersen PK, Geskus RB, de Witte $\mathrm{T}$, et al. Competing risks in epidemiology: possibilities and pitfalls. Int $J$ Epidemiol 2012; 41: 861-870

14. Taramasso L, Di Biagio A, Maggiolo F, et al. First-line antiretroviral therapy with efavirenz plus tenofovirdisiproxil fumarate/emtricitabine or rilpivirine plus tenofovir disiproxil fumarate/emtricitabine : a durability comparison. HIV Medicine 2018; 19: 475-484

15. Nelson M, Amaya $\mathrm{G}$, Clumeck $\mathrm{N}$, et al. Efficacy and safety of rilpivirine in treatmentnaive, HIV-1-infected patients with hepatitis $B$ virus/hepatitis $C$ virus coinfection enrolled in the Phase III randomized, double-blind ECHO and THRIVE trials. JAC 2012; 67: 20202028

16. Stohr W, Dunn DT, Arenas-Pinto A, et al. Factors associated with virological rebound in HIV-infected patients receiving protease inhibitor monotherapy. AIDS 2016; 30: 26172624. 
Table 1. Individual characteristics at RPV initiation according to the group clinical situation

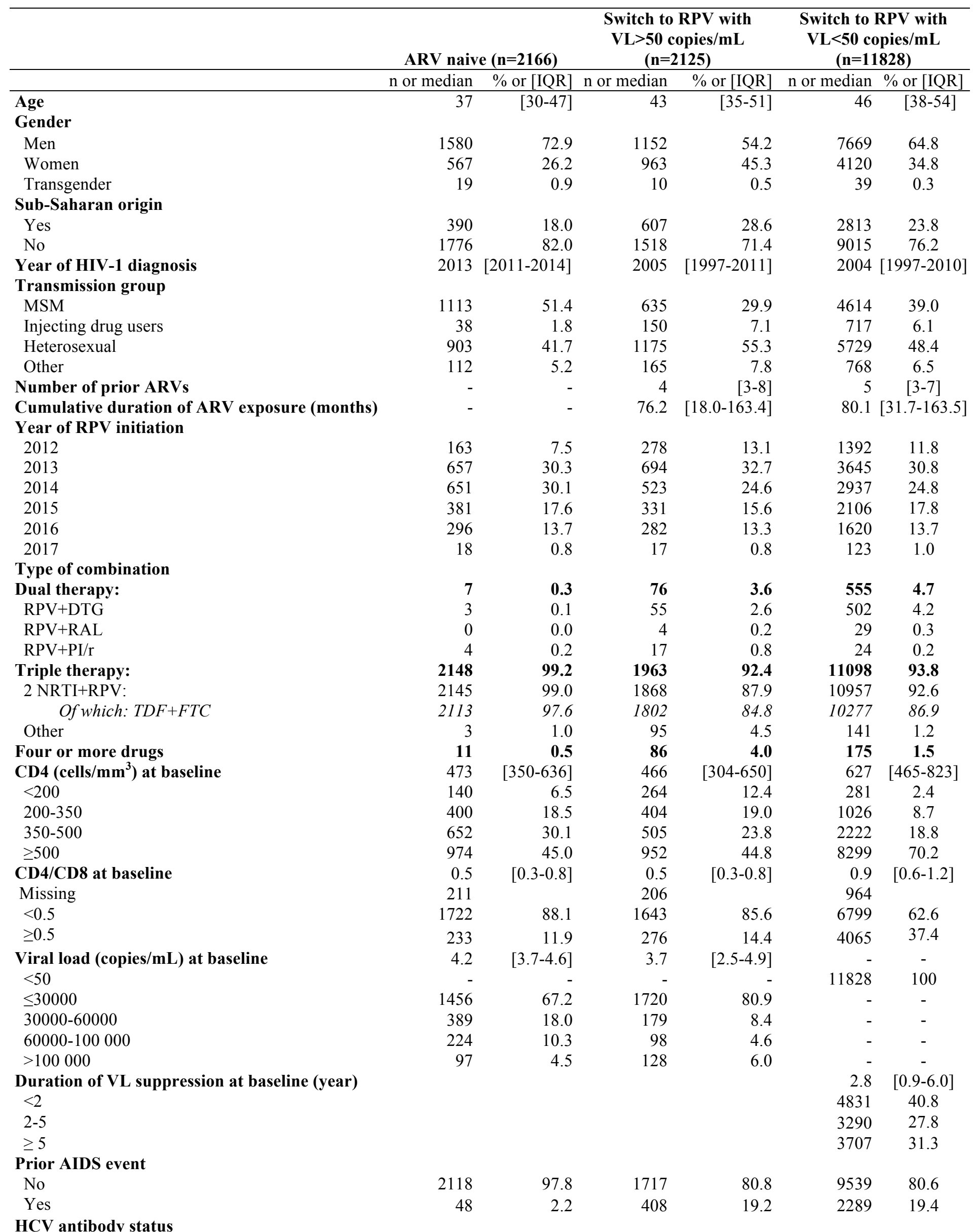




\begin{tabular}{|c|c|c|c|c|c|c|}
\hline & ARV naiv & $(n=2166)$ & $\begin{array}{r}\text { Switch to } \\
\text { VL }>50 \text { c } \\
(n=2\end{array}$ & $\begin{array}{l}\text { RPV with } \\
\text { pies/mL } \\
\text { 25) }\end{array}$ & $\begin{array}{r}\text { Switch to } \\
\mathrm{VL}<\mathbf{5 0} \text { co } \\
(\mathrm{n}=11\end{array}$ & $\begin{array}{l}\text { RPV with } \\
\text { pies/mL } \\
\text { 828) }\end{array}$ \\
\hline & $\mathrm{n}$ or median & $\%$ or $[\mathrm{IQR}]$ & $\mathrm{n}$ or median & $\%$ or $[\mathrm{IQR}]$ & n or median & $\%$ or $[\mathrm{IQR}]$ \\
\hline Positive & 79 & 3.6 & 245 & 11.5 & 1333 & 11.3 \\
\hline HBsAg sta & & & & & & \\
\hline Negative & 2106 & 97.2 & 1994 & 93.8 & 11123 & 94.0 \\
\hline
\end{tabular}

Abbreviations: ARV, antiretrovirals; RPV, rilpivirine; DTG, dolutegravir; RAL, raltegravir; TDF, tenofovir; FTC, emtricitabine; VL, viral load 
Table 2. Factors associated with 48 month virological success among ARV naive individuals: univariable and multivariable competing risk regression analyses. The events "RPV discontinuation", "lost to follow-up" and "deaths" were considered as competing risk for the virological success. $\mathrm{N}=2166$ of whom 1950 reached $\mathrm{VL}<50 \mathrm{copies} / \mathrm{mL}$.

\begin{tabular}{|c|c|c|c|c|}
\hline \multirow[t]{2}{*}{ Characteristics } & \multicolumn{2}{|l|}{ Univariable analysis } & \multicolumn{2}{|c|}{ Multivariable analysis } \\
\hline & $\operatorname{sHR}(95 \% \mathrm{CI})$ & $\mathrm{P}$ & sHR $(95 \% \mathrm{CI})$ & $\mathrm{P}$ \\
\hline Age (per 10-years increment) & $0.98(0.95-1.03)$ & 0.56 & $1.00(0.97-1.05)$ & 0.79 \\
\hline MSM & 1 & 0.02 & 1 & 0.22 \\
\hline Injecting drug users & $0.97(0.64-1.46)$ & & $0.94(0.60-1.48)$ & \\
\hline Other men & $0.83(0.74-0.94)$ & & $0.88(0.78-1.00)$ & \\
\hline Other women & $0.95(0.85-1.06)$ & & $0.92(0.81-1.05)$ & \\
\hline \multicolumn{5}{|l|}{ Sub-Saharan origin } \\
\hline Yes & 1 & 0.21 & 1 & 0.83 \\
\hline No & $1.08(0.96-1.22)$ & & $1.02(0.88-1.18)$ & \\
\hline \multicolumn{5}{|l|}{ Type of combination } \\
\hline Dual therapy & $1.60(0.78-3.27)$ & 0.20 & $1.84(0.89-3.83)$ & 0.10 \\
\hline Triple therapy or more & 1 & & 1 & \\
\hline \multicolumn{5}{|l|}{ VL at baseline (copies/mL) } \\
\hline$\leq 30000$ & 1 & $<0.0001$ & 1 & $<0.0001$ \\
\hline $30000-100000$ & $0.70(0.64-0.77)$ & & $0.71(0.65-0.78)$ & \\
\hline$>100000$ & $0.45(0.37-0.55)$ & & $0.48(0.39-0.58)$ & \\
\hline \multicolumn{5}{|l|}{ Prior AIDS event } \\
\hline No & 1 & 0.07 & 1 & 0.80 \\
\hline Yes & $0.74(0.54-1.02)$ & & $0.96(0.70-1.32)$ & \\
\hline \multicolumn{5}{|l|}{ CD4 (cells/mm³) } \\
\hline$<200$ & $0.65(0.53-0.79)$ & $<0.0001$ & $0.81(0.65-1.01)$ & 0.08 \\
\hline $200-350$ & $0.85(0.75-0.96)$ & & $0.91(0.80-1.04)$ & \\
\hline $350-500$ & $1.00(0.90-1.11)$ & & $1.03(0.93-1.15)$ & \\
\hline$\geq 500$ & 1 & & 1 & \\
\hline \multicolumn{5}{|l|}{ HCV antibody status } \\
\hline Negative & 1 & 0.57 & 1 & 0.88 \\
\hline Positive & $1.08(0.84-0.38)$ & & $1.02(0.77-1.36)$ & \\
\hline \multicolumn{5}{|l|}{ HBsAg status } \\
\hline Negative & 1 & 0.88 & 1 & 0.66 \\
\hline Positive & $1.02(0.77-1.36)$ & & $1.07(0.78-1.47)$ & \\
\hline
\end{tabular}


Table 3. Factors associated with 48 month virological success among ARV experienced individuals switching to RPV with $V L>50$ copies/mL: univariable and multivariable competing risk regression analyses. The events "RPV discontinuation", "lost to follow-up" and "deaths" were considered as competing risk for the virological success. $\mathrm{N}=\mathbf{2 1 2 5}$ of whom 1736 reached $V L<50$ copies $/ \mathbf{m L}$.

\begin{tabular}{|c|c|c|c|c|}
\hline Characteristics & Univariable analysis & & Multivariable analy & \\
\hline & sHR $(95 \% \mathrm{CI})$ & $\mathrm{P}$ & $\operatorname{sHR}(95 \% \mathrm{CI})$ & $\mathrm{P}$ \\
\hline Age (per 10-years increment) & $1.02(0.97-1.06)$ & 0.48 & $1.03(0.97-1.08)$ & 0.28 \\
\hline $\begin{array}{l}\text { Gender and transmission grour } \\
\text { MSM } \\
\text { Injecting drug users } \\
\text { Other men } \\
\text { Other women }\end{array}$ & $\begin{array}{c}1 \\
0.90(0.74-1.09) \\
0.91(0.79-1.04) \\
0.99(0.88-1.10)\end{array}$ & 0.37 & $\begin{array}{c}1 \\
0.94(0.75-1.19) \\
0.93(0.80-1.08) \\
1.05(0.92-1.20)\end{array}$ & 0.31 \\
\hline $\begin{array}{l}\text { Sub-Saharan origin } \\
\text { Yes }\end{array}$ & 1 & 0.68 & 1 & 0.77 \\
\hline No & $1.02(0.92-1.13)$ & & $1.02(0.90-1.15)$ & \\
\hline $\begin{array}{l}\text { Number of prior ARVs } \\
\leq 3 \\
4-6 \\
>6\end{array}$ & $\begin{array}{c}1 \\
0.83(0.74-0.94) \\
0.84(0.75-0.94)\end{array}$ & 0.001 & $\begin{array}{c}1 \\
0.84(0.75-0.95) \\
0.84(0.74-0.95)\end{array}$ & 0.004 \\
\hline $\begin{array}{l}\text { Type of combination } \\
\text { Dual therapy } \\
\text { Triple therapy or more }\end{array}$ & $\begin{array}{c}1.17(0.90-1.51) \\
1\end{array}$ & 0.24 & $\begin{array}{c}1.12(0.85-1.49) \\
1\end{array}$ & 0.42 \\
\hline $\begin{array}{l}\text { VL at baseline (copies/mL) } \\
\leq 30000 \\
30000-100000 \\
>100000\end{array}$ & $\begin{array}{c}1 \\
0.59(0.52-0.67) \\
0.48(0.40-0.58)\end{array}$ & $<0.0001$ & $\begin{array}{c}1 \\
0.65(0.57-0.74) \\
0.55(0.46-0.67)\end{array}$ & $<0.0001$ \\
\hline $\begin{array}{l}\text { Prior AIDS event } \\
\text { No } \\
\text { Yes }\end{array}$ & $0.84(0.74-0.96)$ & 0.008 & $0.97(0.85-1.11)$ & 0.68 \\
\hline $\begin{array}{l}\text { CD4 }\left(\text { cells } / \mathbf{m m}^{\mathbf{3}}\right) \\
<200 \\
200-350 \\
350-500 \\
\geq 500\end{array}$ & $\begin{array}{l}0.55(0.46-0.64) \\
0.86(0.76-0.97) \\
1.03(0.92-1.16) \\
1\end{array}$ & $<0.0001$ & $\begin{array}{l}0.71(0.59-0.86) \\
0.95(0.83-1.09) \\
1.07(0.95-1.21) \\
1\end{array}$ & 0.0004 \\
\hline $\begin{array}{l}\text { HCV antibody status } \\
\text { Negative } \\
\text { Positive }\end{array}$ & $1.01(0.87-1.17)$ & 0.89 & $1.08(0.90-1.30)$ & 0.40 \\
\hline $\begin{array}{l}\text { HBsAg status } \\
\text { Negative } \\
\text { Positive }\end{array}$ & $\begin{array}{c}1 \\
0.98(0.80-1.20)\end{array}$ & 0.86 & $\begin{array}{c}1 \\
1.00(0.81-1.23)\end{array}$ & 0.97 \\
\hline
\end{tabular}


Table 4. Factors associated with virological failure among ARV experienced individuals switching to RPV while maintening viral supression $<\mathbf{5 0}$ copies/mL: univariable and multivariable competing risk regression analyses . The events "lost to follow-up" and "deaths", are considered as competing risk for the virological failure. $\mathrm{N}=11828$ of whom 967 have virological failure.

\begin{tabular}{|c|c|c|c|c|}
\hline \multirow[t]{2}{*}{ Characteristics } & \multicolumn{2}{|l|}{ Univariable analysis } & \multicolumn{2}{|c|}{ Multivariable analysis } \\
\hline & $\mathrm{sHR}(95 \% \mathrm{CI})$ & $\mathrm{P}$ & $\operatorname{sHR}(95 \% \mathrm{CI})$ & $\mathrm{P}$ \\
\hline Age (per 10-years increment) & $0.94(0.88-1.00)$ & 0.04 & $1.03(0.97-1.10)$ & 0.37 \\
\hline \multicolumn{5}{|l|}{ Transmission group } \\
\hline MSM & 1 & $<0.0001$ & 1 & $<0.0001$ \\
\hline Injecting drug users & $1.59(1.22-2.07)$ & & $1.55(1.12-2.15)$ & \\
\hline Other men & $1.68(1.41-2.00)$ & & $1.51(1.26-1.82)$ & \\
\hline Other women & $1.69(1.45-1.98)$ & & $1.56(1.30-1.87)$ & \\
\hline \multicolumn{5}{|l|}{ Sub-Saharan origin } \\
\hline Yes & 1 & $<0.0001$ & 1 & 0.13 \\
\hline No & $0.67(0.59-0.77)$ & & $0.88(0.75-1.04)$ & \\
\hline \multicolumn{5}{|l|}{ Type of combination } \\
\hline Dual therapy & $0.62(0.40-0.94)$ & 0.02 & $0.75(0.49-1.15)$ & 0.19 \\
\hline Triple therapy or more & 1 & & 1 & \\
\hline $\begin{array}{l}\text { Duration of VL suppression at baseline } \\
\text { (per 1-year increment) }\end{array}$ & $0.88(0.86-0.90)$ & $<0.0001$ & $0.88(0.86-0.90)$ & $<0.0001$ \\
\hline \multicolumn{5}{|l|}{ Prior AIDS event } \\
\hline No & 1 & 0.0001 & 1 & 0.0008 \\
\hline Yes & $1.33(1.15-1.55)$ & & $1.30(1.12-1.52)$ & \\
\hline \multicolumn{5}{|l|}{ CD4 (cells $\left./ \mathbf{m m}^{3}\right)$} \\
\hline$<200$ & $2.37(1.74-3.24)$ & $<0.0001$ & $1.61(1.17-2.21)$ & 0.0004 \\
\hline $200-350$ & $1.79(1.48-2.17)$ & & $1.40(1.14-1.70)$ & \\
\hline $350-500$ & $1.36(1.17-1.60)$ & & $1.20(1.02-1.41)$ & \\
\hline$\geq 500$ & 1 & & 1 & \\
\hline \multicolumn{5}{|l|}{ HCV antibody status } \\
\hline Negative & 1 & 0.20 & 1 & 0.16 \\
\hline Positive & $1.13(0.94-1.37)$ & & $1.19(0.94-1.52)$ & \\
\hline \multicolumn{5}{|l|}{ HBsAg status } \\
\hline Negative & 1 & 0.17 & 1 & 0.32 \\
\hline Positive & $1.19(0.93-1.53)$ & & $1.14(0.88-1.47)$ & \\
\hline
\end{tabular}


Fig. 1. Cumulative incidence of virological success ( $V L<50$ copies $/ \mathrm{mL}$ ) according to $V L$ at baseline in (a) ARV-naïve individuals and (b) ARV-experienced individuals switching to RPV while failing therapy

a. ARV naïve individuals $(n=2166)$

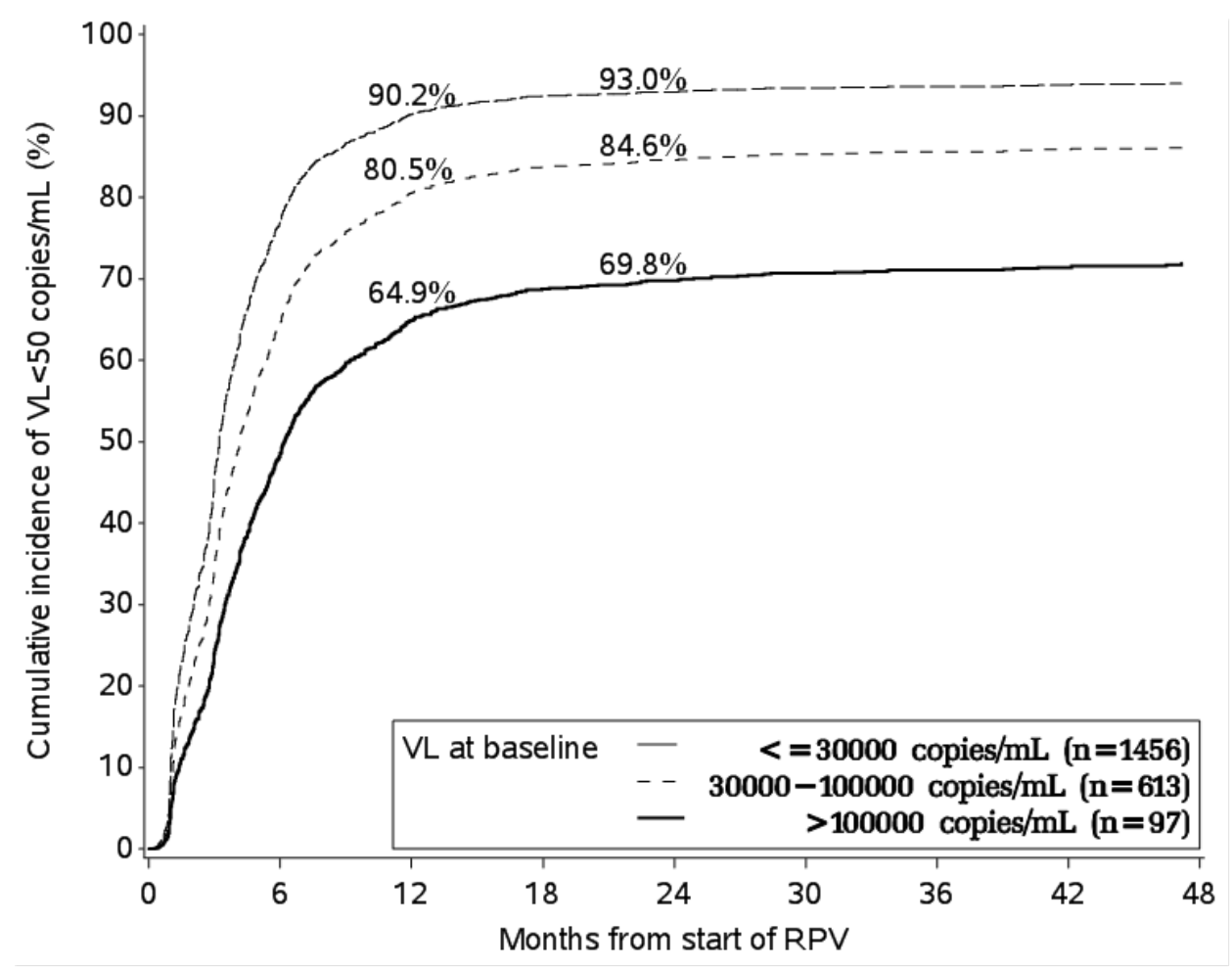

The cumulative incidence of $\mathrm{VL}<50$ copies/mL was estimated considering RPV discontinuation, loss to follow-up and death as competing risks

b. ARV-experienced individuals switching to RPV while failing therapy $(n=2125)$

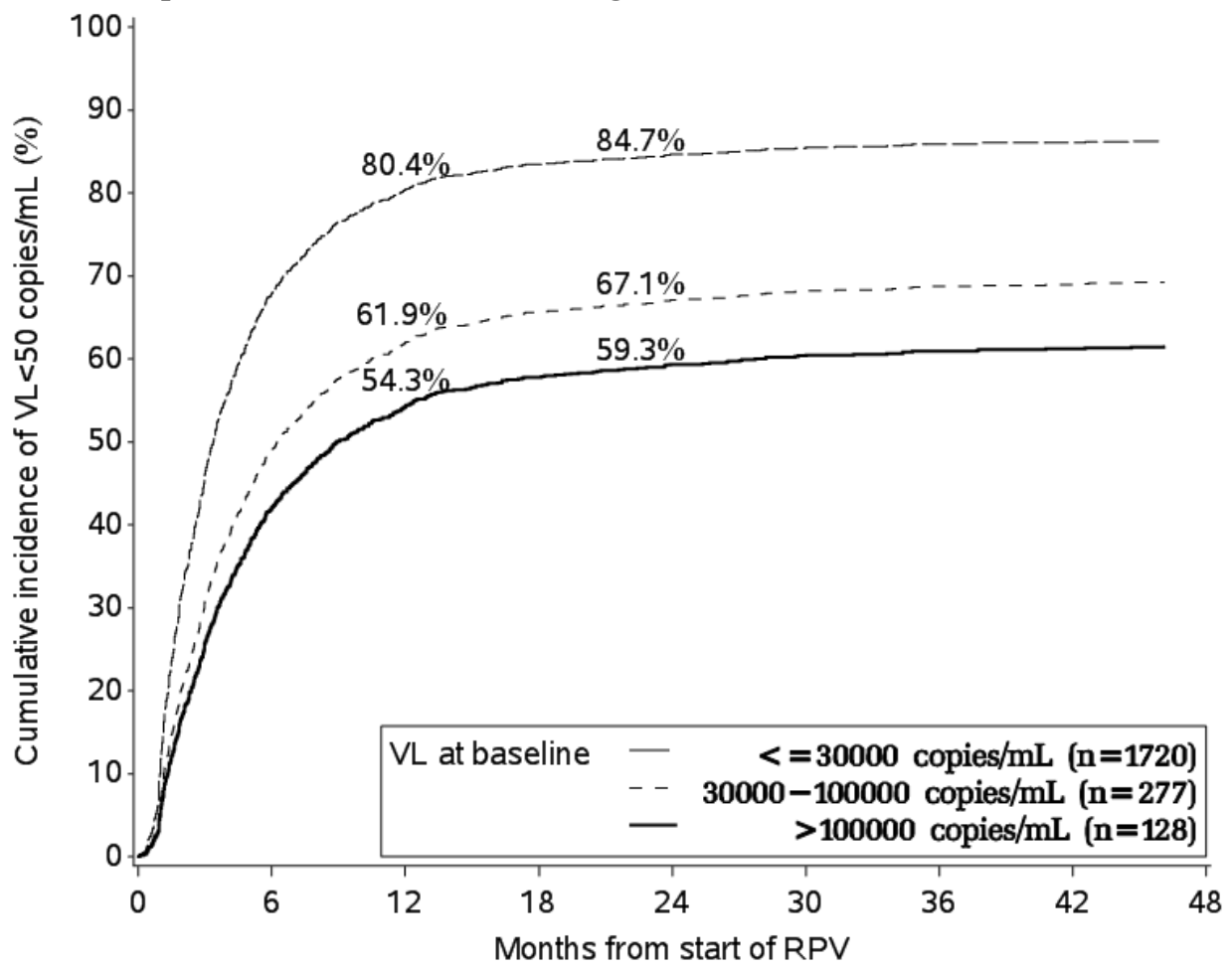

The cumulative incidence of $\mathrm{VL}<50$ copies/mL was estimated considering RPV discontinuation, loss to follow-up and death as competing risks 
Fig. 2. Cumulative incidence of virological failure (two consecutive $V L>50$ copies $/ \mathrm{mL}$ or one $V L>50 \mathrm{copies} / \mathrm{mL}$ followed by a treatment switch prior to another VL measurement) according to (a) duration of viral suppression prior to baseline and (b) type of combination for ARV-experienced individuals switching to RPV while virologically controlled $(n=11828)$

a. Duration of viral suppression prior to baseline

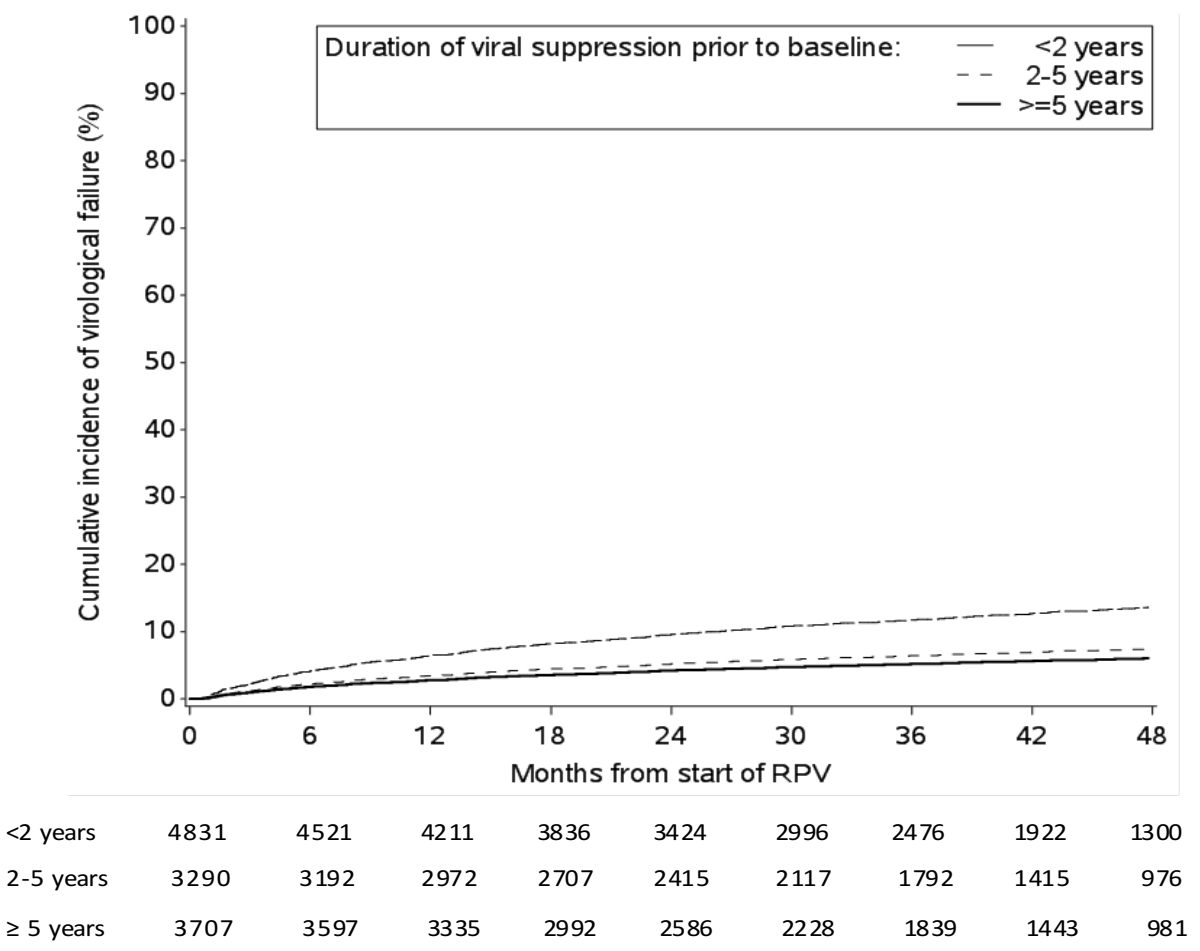

The cumulative incidence of virological failure was estimated considering loss to follow-up and death as competing risks

\section{b. Type of combination}

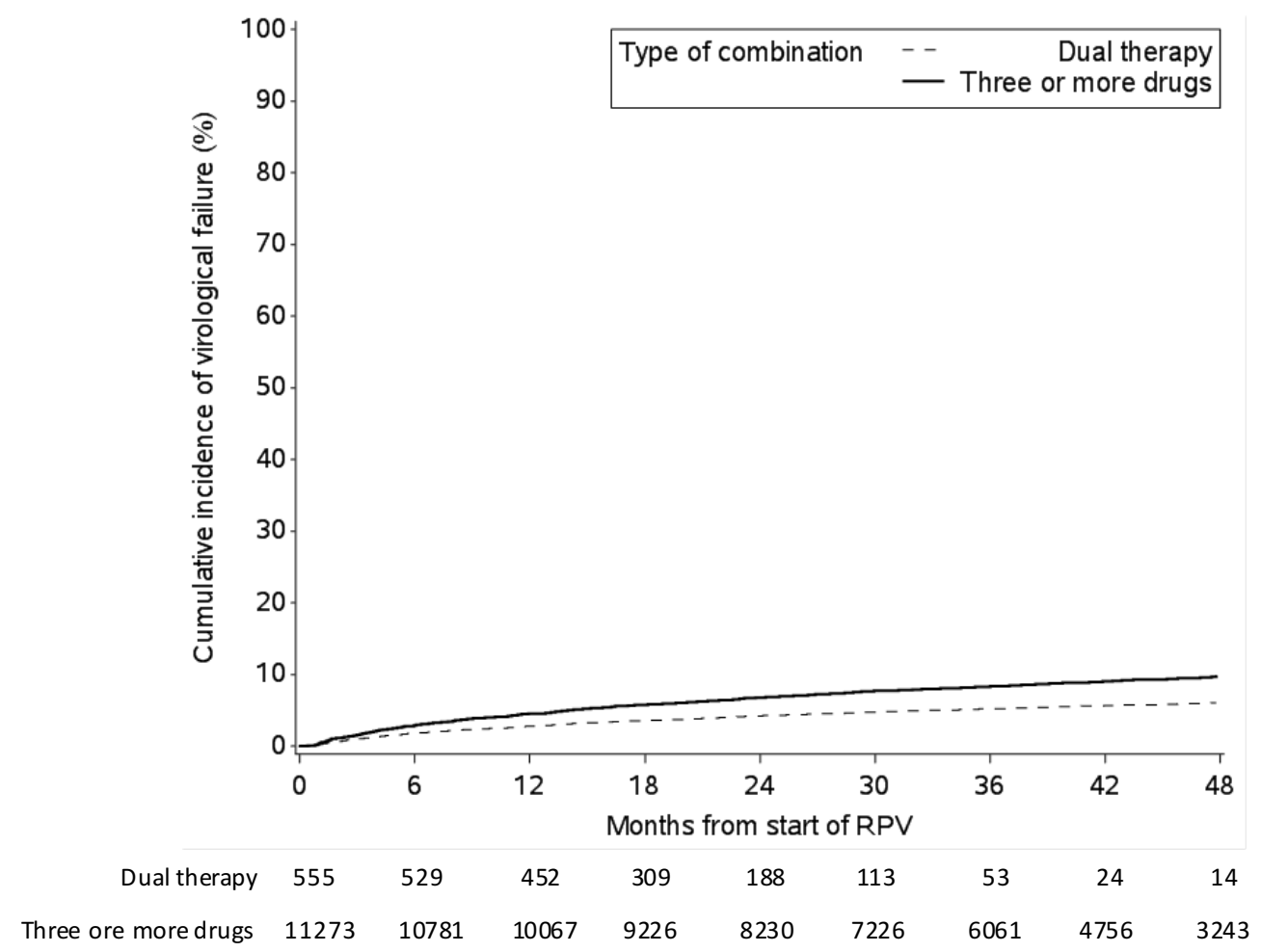

The cumulative incidence of virological failure was estimated considering loss to follow-up and death as competing risks 